\title{
Usmerjenost k uporabniku kot načelo delovanja javne uprave
}

\author{
UDK: 35. 086 (497.12)
}

\section{Gregor Virant}

Ministrstvo za notranje zadeve, UORU

gregor.virant@gov.si

\begin{abstract}
IZVLEČEK
Usmerjenost k uporabniku je eno od načel, ki jih zasleduje reforma javne uprave v Sloveniji. $V$ tem okviru se javna uprava trudi povečati zadovoljstvo strank $z$ njenimi storitvami. Meje usmerjenosti k uporabniku določa javni interes. Pri izboljševanju kakovosti upravnih storitev je potrebno na strateški ravni odločanja kombinirati pristop od zgoraj navzdol (uvajanje novih idej in projektov, ki jih domača praksa še ne pozna) s pristopom od spodaj navzgor (vznik iniciativ v posameznih institucijah, razvoj in promocija dobrih praks). Za zadovoljstvo uporabnika so pomembni naslednji elementi upravne storitve: informacija o storitvi, prostorska in časovna dostopnost, enostavnost naročila, postopka in plačila, kakovost osebnega stika, strokovnost in urejenost uslužbencev, urejenost poslovnih prostorov, odzivnost na kritike, pripombe, predloge in pohvale ter zanesljivost. Na zadovoljstvo uporabnika bistveno vpliva tudi spoštovanje »klasičnih « načel delovanja uprave, to je načel zakonitosti, pravne varnosti in predvidljivosti, politične nevtralnosti in odgovornosti javne uprave. $V$ slovenski javni upravi so bili uvedeni številni ukrepi za izboljševanje navedenih elementov. Problem, ki ga je treba preseči $v$ naslednjem obdobju, je razkorak med normativnim in stvarnim, med predpisi in realnostjo. Bistvo nadaljevanja reforme javne uprave je torej v doslednem izvajanju sprejetih zakonov in podzakonskih predpisov na vseh področjih. To pa bo mogoče doseči $z$ učinkovitim nadzorom, usposabljanjem menedžerskih struktur in drugih uslužbencev $v$ javni upravi in s spreminjanjem organizacijske kulture $v$ javni upravi.
\end{abstract}

Ključne besede: reforma javne uprave, usmerjenost javne uprave $k$ uporabniku, kakovost upravnih storitev, informacije o upravnih storitvah, e-uprava, odpravljanje administrativnih ovir.

\section{Reforma javne uprave in zadovoljstvo uporabnikov}

$\checkmark$ reformah javnih uprav vseh evropskih držav, vključno z državami pristopnicami k Evropski uniji (EU), ima pomembno mesto načelo usmerjenosti $k$ uporabniku. $\vee$ zgodovinskem razvoju javnih uprav je ta vrednota relativno mlada in je povezana s prodorom novega javnega menedžmenta, ki $v$ javni sektor uvaja načela in metode, uveljavljene $v$ zasebnem sektorju. Podobno velja tudi za upravljanje kakovosti, ki je z zadovoljstvom uporabnikov tesno povezano. Tradicionalna definicija 


\section{Gregor Virant \\ Usmerjenost k uporabniku kot načelo delovanja javne uprave}

kakovosti je namreč skladnost med pričakovano in dobljeno storitvijo, kar pomeni, da je kakovost delovanja premosorazmerna z zadovoljstvom uporabnikov. Novejše definicije kakovosti so širše in moderni modeli merjenja in izboljševanja kakovosti poslovanja upoštevajo številne druge elemente (zlasti zadovoljstvo zaposlenih, vpliv na okolje, $v$ javnem sektorju pa tudi vpliv na družbo). Usmerjenost $k$ uporabniku je našla svoje mesto na političnem dnevnem redu in se marsikje tudi uspešno uresničuje $v$ praksi, ker je politično vabljiva in zahteva od političnih elit relativno majhne "žrtve ( $z$ izvajanjem depolitizacije in profesionalizacije je zlasti v državah kandidatkah več težav, ker zmanjšujeta možnost političnih elit, da javno upravo jemljejo kot plen, možnost za ugodno zaposlitev svojih pripadnikov itd.).

Zadovoljstvo uporabnikov, prijazna uprava, antibirokratski programi in odpravljanje administrativnih ovir so izrazi, ki so postali del političnega besednjaka. Javna uprava jih praviloma sprejema pozitivno toliko, kolikor so realistični in kolikor upoštevajo njene posebnosti. Realizem $v$ tem kontekstu pomeni, da ne smemo obljubljati več, kot je objektivno mogoče. Če bomo zaradi večjega zadovoljstva strank čez noč povečali obremenitve javnih uslužbencev za sto odstotkov, da bi npr. odpravili zaostanke, bo lahko prišlo do negativnih učinkov - zaposleni bodo nezadovoljni in bodo svoje nezadovoljstvo stresali na uporabnike, nekateri zaposleni pa bodo verjetno zapustili službo. Prav tako narobe bi bilo obljubljati informatizacijo upravnih storitev čez noč, če ideja ni podprta z zadostnimi sredstvi.

Ob prizadevanjih za povečanje zadovoljstva uporabnikov je treba vedno upoštevati tudi posebnosti javne uprave. Usmerjenost k uporabniku ima meje, ki jih postavlja javni interes. Zadovoljstva uporabnika ne smemo postavljati pred interese drugih ali pred javni interes, ki ga določa zakon. Javna uprava, ki bi podlegla tej skušnjavi, bi imela zadovoljne individualne uporabnike, a družba kot celota bi bila z njenim delom nezadovoljna. Javna uprava včasih svojo kakovost izkaže tako, da uporabnika ne zadovolji (ko npr. zavrne njegovo zahtevo za gradbeno dovoljenje ali socialno pomoč, če ne izpolnjuje zakonskih pogojev). Tudi sicer je nezadovoljstvo uporabnikov delno vgrajeno $v$ poslovanje javne uprave, saj javnost (zlasti manj izobraženi) njenega delovanja pogosto ne dojema kot zadovoljevanja svojih potreb, temveč kot (birokratsko) oviro na poti do zadovoljevanja potreb (npr. pri gradnji hiše) ali pa vsaj kot nujno zlo. $\vee$ tem pogledu so številne službe $v$ javni upravi bolj stresne kot $v$ zasebnem sektorju. Prodajalec avtomobilov ima opravek z ljudmi, ki jih že samo dejstvo, da kupujejo avtomobil, spravlja $\vee$ zadovoljstvo; težko pa bi to trdili za uradnika, ki podaljšuje vozniška dovoljenja ali izdaja gradbena dovoljenja. Še bolj to seveda velja za represivne dele javne uprave in za tiste, ki državljanom in pravnim osebam nalagajo obveznosti.

Ovira za doseganje večjega zadovoljstva uporabnikov je tudi dejstvo, da imajo ponudniki upravnih storitev večinoma monopolni položaj, da ne obstaja prosta konkurenca. Zato upravne institucije nezadovoljstvo uporabnikov ogroža bistveno manj kot podjetja, ki se morajo iz dneva $v$ dan boriti za ohranitev in povečanje števila 
strank. Tudi naloge javne uprave se lahko opravljajo konkurenčno (privatizacija), vendar so države pri privatizaciji praviloma previdne, ker privatizacija upravnih (oblastnih) nalog lahko ogroža javni interes. Privatizacija in vzpostavitev konkurence, kjer je to mogoče, sta dobrodošla ukrepa, ki pozitivno vplivata na zadovoljstvo strank (nevarnost pa je zlasti $v$ tem, da se zanemari interes tretjih oseb, ki niso neposredni uporabniki, in javni interes). Ob pomanjkanju trga pa so za povečevanje kakovosti storitev in zadovoljstva uporabnikov na voljo različni netržni mehanizmi. Ker se nezadovoljstvo javnosti z delovanjem uprave in povečana pričakovanja glede kakovosti storitev kažejo kot pritisk na politične stranke in vlado, vlada z obvezujočimi standardi (predpisi) usmerja upravne organe $k$ uporabniku. Vzpostavljanje družbene klime, ki postavlja javni upravi višje zahteve, vpliva tudi na vse večje število entuziastov, ki se projektov izboljševanja kakovosti, uvajanja inovativnih rešitev in povečevanja zadovoljstva strank lotevajo brez palice in korenčka, na lastno pobudo, ponavadi v sodelovanju s somišljeniki. Ne gre pozabiti, da imajo upravne institucije, njihovi menedžerji in zaposleni mnogo neposrednejši stik in izkušnje z uporabniki svojih storitev kot politiki; uradnikom in njihovim menedžerjem ni vseeno, kaj si o njih mislijo njihove stranke in okolje, $v$ katerem živijo. Iz navedenih razlogov $v$ javni upravi vzniknejo t. i. dobre prakse, ki jih modra vlada ob pravem trenutku promovira $\checkmark$ širšem krogu institucij javne uprave ali $v$ trenutku, ko je dosežena kritična masa oziroma so vzpostavljene možnosti, naredi iz njih obvezne standarde.

Povečevanje kakovosti storitev in zadovoljstva strank je kontinuiran projekt, pri katerem je dobro kombinirati pristop od spodaj navzgor s pristopom od zgoraj navzdol. V strateškem centru reforme javne uprave mora obstajati posluh za dobre ideje iz prakse in dober občutek za pravi trenutek, ko se dobre prakse pretvorijo $v$ obvezen standard. Seveda pa je naloga strateškega centra tudi $\vee$ tem, da uvede nove ideje in projekte, ki jih domača praksa še ne pozna (zlasti tiste, ki so se uspešno uveljavili v drugih državah). Njegova pomembna vloga je tudi, da ustrezno organizira pobude (z oblikovanjem projektnih skupin, odborov za kakovost itd.).

\section{Elementi kakovosti upravne storitve}

\subsection{Splošno}

Zadovoljstvo uporabnika je odvisno od številnih elementov storitve, med katerimi je treba poudariti zlasti naslednje:

- informacije o upravnih storitvah,

- prostorska in časovna dostopnost,

- enostavnost naročila, postopka in plačila,

- kakovost osebnega stika, strokovnost in urejenost uslužbenca,

- urejenost poslovnih prostorov,

- odzivnost na kritike, pripombe, predloge in pohvale ter

- zanesljivost. 


\section{Gregor Virant \\ Usmerjenost k uporabniku kot načelo delovanja javne uprave}

V širšem smislu kakovost upravne storitve zajema tudi nekatera klasična pravnopolitična načela (zakonitost, pravna varnost in predvidljivost, objektivnost in nepristranskost). Uresničevanje nekaterih izmed teh načel (zakonitost, nepristranskost) je $\vee$ celoti $v$ rokah organa, ki stopa $\vee$ stik $s$ stranko, pri nekaterih drugih načelih pa je implementacijski organ odvisen od kakovosti politik oziroma predpisov, ki urejajo njegova ravnanja. Sicer pa velja enako tudi za zgoraj navedene elemente kakovosti. Enostavnost postopka je le deloma odvisna od implementacijskega organa, bolj pa od vsebine predpisov, ki so $v$ rokah oblikovalcev politik (policy-makers).

\subsection{Informacije o upravnih storitvah}

Omenjeno je že bilo, da je stik z javno upravo uporabniku praviloma nadležen. Posamezniki tradicionalno pojmujejo javno upravo kot težko razumljiv aparat, ki nastopa $v$ razmerju do njih z državno avtoriteto. Zato je velikega pomena, da se uporabnikom zagotovijo informacije o upravnih storitvah, s pomočjo katerih bo uprava bolj transparentna, uporabnik pa bo lažje predvideval odločitve uprave. Informacije morajo biti zagotovljene $v$ različnih oblikah (osebni stik, telefon, elektronska pošta, brošure, internet), tako da je uporabniku zagotovljena svoboda izbire. Informacije morajo biti podane na uporabniku prijazen in razumljiv način. Pri njihovem sestavljanju je treba izhajati iz logike uporabnika in njegove življenjske situacije, ne pa iz logike javne uprave oziroma njenih uradnikov. Jezik, ki ga uporablja informacijsko gradivo, mora biti razumljiv slehernemu uporabniku. Informacije morajo odgovarjati na ključna vprašanja (kje, kako, kdaj, koliko stane). Sistem informacij mora biti čim enotnejši; idealno je, če za celotno javno upravo obstaja enotna struktura informacij (npr. internetni storitveni portal).

\subsection{Prostorska in časovna dostopnost storitev}

Prostorska dostopnost pomeni, da lahko uporabnik storitev naroči in vse stike z javno upravo, potrebne za izvedbo storitve, opravi na svojemu stanovanju ali poslovnemu sedežu čim bližji lokaciji. Razvoj e-uprave omogoča stik z upravo od doma oziroma iz pisarne, če javna uprava na internetu ponuja storitve na ravni transakcije - to pomeni, da lahko uporabnik storitev naroči po elektronski poti in na isti način javni upravi dostavi tudi vse potrebne dokumente. Ta raven storitev običajno zahteva uporabo elektronskega podpisa kot načina identifikacije uporabnika in avtentikacije dokumenta.

Načelo uvajanja e-uprave je, da naj bi javna uprava na internetu ponudila vse storitve, če je to mogoče in smotrno. Prednost morajo imeti stiki z javno upravo, ki so za uporabnike pogostejši. Pogoste stike z javno upravo imajo podjetja, zato je 


\section{Usmerjenost $\quad$ Gregor Virant}

dodana vrednost e-storitev nedvomno bistveno večja pri podjetjih. Državljanom se zdi e-uprava zanimiva novost, vendar se redkeje odločajo za nabavo elektronskega podpisa, ker so njihovi stiki z javno upravo relativno redki. Uporabo e-storitev spodbuja uvedba možnosti uporabe elektronskih potrdil, ki se uporabljajo $\vee$ bančnem poslovanju. Elektronsko poslovanje na tem področju je med državljani zelo razširjeno, zato jih ima veliko število na voljo digitalna potrdila. Ni videti razloga, da s temi digitalnimi potrdili, če izpolnjujejo varnostne standarde, ne bi bilo mogoče poslovati tudi z javno upravo

Prostorsko dostopnost storitev povečuje tudi možnost komunikacije po telefonu, po elektronski ali navadni pošti. Praviloma se lahko vse komunikacije opravijo po elektronski ali navadni pošti, pri čemer je elektronska pošta lahko spet vezana na uporabo elektronskega podpisa. $\vee$ dobi e-poslovanja bo za zadovoljstvo uporabnikov izjemno pomembno, da javna uprava klasificira vrste komunikacij po zahtevani stopnji varnosti. Uporabniki bodo nezadovoljni, če bo zahtevana varnost pretirana. Zdi se, da ob "prevajanju « fizične komunikacije v elektronsko pogosto pretiravamo $\vee$ varnostnih zahtevah in vidimo nevarnosti, ki jih pri fizičnem poslovanju nismo videli, čeprav so prav tako obstajale. Na primer: pri pošiljanju davčnih napovedi po navadni pošti za identifikacijo avtorja zadošča lastnoročni podpis, katerega avtentičnosti v praksi davčna uprava nikoli ne preverja. To tudi ni potrebno, saj se morebitne zlorabe hitro odkrijejo (če npr. davčna uprava prejme dve napovedi od istega zavezanca ali pa če se zavezanec pritoži na odmero davka). Zakaj bi torej za elektronsko pošiljanje davčne napovedi zahtevali elektronski podpis državnega overitelja, ko pa elektronski podpis, overjen od licenciranega overitelja, zagotavlja bistveno višjo stopnjo varnosti kot lastnoročni podpis?

Poslovanje po telefonu je pri upravnih storitvah omejeno zaradi oteženega preverjanja identitete. Kljub temu pa je po telefonu mogoče dobiti informacije o storitvah ter opraviti manj pomembna posvetovanja in preverjanja, namesto da se stranka vabi na lokacijo organa.

Prostorska dostopnost je odvisna tudi od lokacijske razporejenosti javne uprave. Javna uprava mora biti teritorialno dekoncentrirana, tako da zagotavlja fizično bližino svojih storitev uporabnikom. Večja ko je frekvenca nekega upravnega postopka, večja je potreba po dekoncentraciji. Seveda je težnja po dekoncentraciji omejena s težnjo po učinkovitosti. Izpostave nekega urada se ne splača locirati v manjši kraj, kjer bi po storitvah povpraševalo le nekaj uporabnikov tedensko.

Časovna dostopnost storitev pa pomeni, da je treba uporabniku zagotoviti, da do storitve pride $v$ čim krajšem času. Za storitve, ki se opravljajo takoj (na okencu), to pomeni čim krajše čakalne vrste ali vsaj lajšanje čakanja (števci vrst in podobni ukrepi), za druge storitve pa, da je predpisan rok in da se organi tega roka tudi držijo. Najpomembnejši ukrep na tem področju je zmanjševanje zaostankov pri reševanju upravnih zadev. 


\section{Gregor Virant}

\section{Usmerjenost $k$ uporabniku kot načelo delovanja javne uprave}

\subsection{Enostavnost naročila, postopka in plačila}

Odpravljanje administrativnih ovir ali t. i. "antibirokratski programi« so sestavni del reform javnih uprav po vsem svetu. Kreatorji sprememb želijo poenostaviti upravne postopke, tako da jih uporabniki ne bi doživljali kot birokratske odisejade. Tega ne delajo samo z namenom olajšati življenje povprečnemu državljanu, temveč zlasti z namenom znižati bremena in stroške podjetjem in podjetnikom na poti do začetka opravljanja gospodarske dejavnosti ali pri opravljanju te dejavnosti. Enostavnost postopka pomeni časovne in finančne prihranke (zato je ta element povezan z elementom časovne dostopnosti), pa tudi prihranek človeške energije in živcev. Pri tem je treba ločiti dve vrsti poenostavitev: prva je politične, druga pa zgolj administrativno-tehnične oziroma organizacijsko-procesne narave. $V$ prvem primeru govorimo o liberalizaciji - pojavu, ko se država in njena uprava umikata z določenih področij družbenega življenja in prepuščata odločitev in odgovornost posameznikom in pravnim osebam. Odpravljajo se različna dovoljenja in licence, rahljajo se pravila ravnanja, katerih spoštovanje nadzira javna uprava. Liberalizacija je političen proces, ker vsaka "osvoboditev« zasebne sfere terja politično ovrednotenje morebitne škode, ki nastane za javni interes. Ukinitev dovoljenj za manjše posege v prostor npr. povečuje svobodo investitorjev in spodbuja investicije, po drugi strani pa lahko ogroža urejenost prostora in interese soseske.

Drugi tip poenostavljanja postopkov pa nima političnega naboja. Njegova vsebina je $v$ tem, da se isti javni interes $v$ neokrnjenem obsegu zavaruje na tehnično enostavnejši način. Poenostavljajo se obrazci, iz postopka se izločijo sestavine, ki za varovanje zakonitega javnega interesa nimajo nobenega pomena, različne kontrole se koncentrirajo na enem mestu, upravni organi zbirajo podatke in dokumente namesto uporabnika in ipd. Teži se $k$ integraciji postopkov, vezanih na določeno življenjsko situacijo ali status, in njihovo koncentracijo na eno mesto (one-stop shop). Po tej zamisli naj bi uporabnik vse, kar je povezano z določeno situacijo ali statusom, opravil na enem mestu. Tam bi dobil vse potrebne informacije, obrazce, tam bi lahko vložil vlogo in spremljal njeno reševanje, tja bi bil vabljen na razgovor itn.

\subsection{Kakovost osebnega stika, zanesljivost, urejenost prostorov}

$\checkmark$ tej točki govorimo o prijaznosti javne uprave $v$ ožjem pomenu besede. "Prijazna javna uprava" $\vee$ širšem smislu zajema vse elemente zadovoljstva uporabnikov, ki jih naštevamo $v$ tem prispevku. $V$ ožjem pomenu besede pa prijaznost pomeni kakovosten osebni, človeški stik. Prijazna beseda in nasmeh imata čarobno moč. Uporabniki upravnih storitev pripisujejo kakovosti osebnega stika velik pomen. Uslužbenec, ki obvlada odnose z uporabniki, lahko ublaži napete situacije, ki jih 
povzročajo zapletena zakonodaja, neurejeni prostori, vrste in zaostanki. Kakovost osebnega stika je element, ki ga je najtežje uveljaviti s prisilnimi standardi in ukrepi. Nasmeha in prijaznosti pač ni mogoče zaukazati. Veščin komuniciranja s strankami se je mogoče priučiti, sposobnost pa je bolj ali manj prirojena in stvar značaja. Zato je pomembno, da v "prve vrste« razporedimo posameznike, ki imajo te sposobnosti, hkrati pa jim zagotovimo ustrezne programe usposabljanja. Poleg tega ne smemo pozabiti, da bo zadovoljen človek najbolj motiviran, da zadovoljstvo prenaša na drugega. Zato je zadovoljstvo zaposlenih pomemben dejavnik zadovoljstva uporabnikov.

Ljudje cenimo zanesljivost $v$ zasebnih in poslovnih stikih. Uporabnik bo zadovoljen, če bodo uradniki držali besedo in opravili storitev $v$ roku in na način, kot so obljubili, in nezadovoljen, če bodo dajali nerealne obljube, ki jih ne bodo mogli uresničiti. T. i. državljanske listine (citizen's charters), ki jih uvajajo v nekaterih evropskih državah kot zbir obljub o standardu storitev, lahko povzročijo več škode kot koristi, če se jih ne držimo.

Za zadovoljstvo uporabnika so pomembni tudi urejeni poslovni prostori. Ti ustvarijo pri uporabniku prijeten občutek, poleg tega pa le primerni in urejeni prostori olajšujejo čakanje $v$ vrstah. Investiranje $\vee$ poslovne prostore, $v$ katerih prihaja do komunikacije $z$ uporabniki, je zato velikega pomena za zadovoljstvo uporabnikov.

\subsection{Odzivnost}

Vsaka organizacija, ki ji je mar za zadovoljstvo uporabnikov, tenkočutno prisluhne njihovemu mnenju, oceni in želji. Tudi institucije javne uprave morajo sistematično spremljati zadovoljstvo uporabnikov in iz ugotovitev izpeljati ustrezne sklepe in ukrepe. Poleg tega morajo spremljati sprotne kritike, pripombe, predloge in tudi pohvale na račun svojega dela. Omogočiti morajo uporabnikom, da ta stališča posredujejo na različne načine (pisno, ustno, $v$ knjigah pritožb in pohval, $\vee$ posebnih nabiralnikih, anonimno ali podpisano, po telefonu in v rubrikah "pišite nam « na domačih spletnih straneh). Na sporočila je treba odgovarjati v razumnem roku in $v$ nebirokratskem tonu, tudi tedaj, kadar menimo, da uporabnik nima prav ali pa njegovim željam iz objektivnih razlogov ne moremo ugoditi. Dejstvo, da smo ga poslušali, vzeli resno, obravnavali njegove pripombe, za katere si je vzel čas, in mu odgovorili, bo na uporabnika naredilo dober vtis. Poleg tega individualnega učinka pa je pomemben tudi splošni učinek, kajti kritike in predlogi nam včasih odprejo oči za boljše rešitve. 


\section{Gregor Virant}

Usmerjenost $k$ uporabniku kot načelo delovanja javne uprave

\section{Ukrepi za dvig zadovoljstva uporabnikov slovenske javne uprave}

Obvladovanje kakovosti in razmerij do uporabnikov je sestavni del procesov modernizacije javne uprave tudi v Sloveniji. Slovenska javna uprava je morala sicer $\checkmark$ letih od osamosvojitve (1991) opraviti številne pomembne naloge, ki so postavile prizadevanja za večjo kakovost na drugo prednostno raven. Treba je bilo zgraditi upravo samostojne države, ki je prevzela funkcije nekdanje zvezne uprave. Upravo je bilo treba prilagoditi novemu demokratičnemu političnemu sistemu in ustavnemu redu (sprejem ustave konec leta 1991). Leta 1997 se je začel pogajalski in predpristopni proces, katerega sestavni del je bila tudi zagotovitev upravne usposobljenosti za izvajanje evropskega pravnega reda in izpolnitev političnih kriterijev, ki so se nanašali tudi na reformo javne uprave. Osamosvojitev, vzpostavitev novega političnega in ustavnega sistema in vključitev v EU so bili projekti velikih razsežnosti, v katerih je javna uprava igrala pomembno vlogo. $\vee$ predpristopnem procesu se je slovenska javna uprava srečala z javnimi upravami držav članic in to je spodbudilo razvoj projektov na nekaterih področjih, ki so bila dotlej zanemarjena.

Sistematična prizadevanja za dvig kakovosti in zadovoljstva uporabnikov so se začela leta 1999, ko je bil pod okriljem urada za organizacijo in razvoj uprave na ministrstvu za notranje zadeve ustanovljen odbor za kakovost, vlada pa je leto kasneje sprejela izjavo o kakovosti. Leta 2001 je bila sprejeta uredba o poslovanju organov javne uprave $s$ strankami, ki je številne dobre prakse $v$ javni upravi uveljavila kot obvezni standard, leto kasneje pa sta bila novelirana zakon o splošnem upravnem postopku in zakon o upravnih taksah, oba z namenom poenostavitve postopkov. Leta 2002 je bil $v$ javno upravo vpeljan evropski model ocenjevanja kakovosti (C. A. F.), leta 2003 pa sprejet zakon o dostopu do informacij javnega značaja. To je le nekaj pomembnejših dokumentov - mejnikov na poti $k$ izboljševanju kakovosti storitev. Poglejmo, kakšni ukrepi so bili izvedeni po posameznih elementih kakovosti storitev oziroma zadovoljstva strank, naštetih zgoraj ( $v$ 2. točki).

\subsection{Informacije o upravnih storitvah}

Upravni organi ponujajo informacije o svojih storitvah $v$ različnih oblikah in različno strukturirane. Najcelovitejša ponudba informacij je dostopna na storitvenem portalu upravnih enot (http://upravneenote.gov.si/upravneenote/) oziroma $\vee$ t. i. vodniku upravnih storitev, ki je sestavni del tega portala. Vodnik vsebuje informacije o približno 150 upravnih storitvah (postopkih). Informacije so strukturirane po področjih (dokumenti, potrdila in tujci; registracija vozil in cestni promet; gradnja; rojstvo, zakonska zveza itd.), znotraj teh pa po sistemu opisov življenjskih položajev 
(kako opravim šoferski izpit, želim graditi nov objekt, rad-a bi spremenil-a ime... ). Pod posameznimi opisi je še raven podrobnejših opisov, kjer uporabnik najde konkretno upravno storitev (upravni akt, upravni postopek). Na voljo so informacije o tem, kdo lahko pridobi storitev, kje jo pridobi, pravna podlaga, višina upravne takse (tu uporabnik najde povezavo do podatka o načinu plačila) in dodatne informacije. Posebej je navedeno tudi, katere priloge je treba priložiti vlogi in katere podatke bo za uporabnika zbrala javna uprava sama. Obrazec vloge je na voljo $\vee$ Wordovem formatu in $v$ formatu pdf. Za zdaj znotraj portala še ni mogoče elektronsko podpisovanje in pošiljanje po elektronski poti.

Na podlagi pozitivnih odzivov na portal upravnih enot je bil takšen način nudenja informacij s spremembo Uredbe o načinu poslovanja organov javne uprave s strankami (Uradni list RS, št. 22/2001 in 81/2003) predpisan kot obvezni standard. Splošne informacije o upravnih storitvah mora vsak organ zagotavljati s svojimi uslužbenci (za vsako področje mora biti uslužbenec na voljo strankam za osebni stik ali po telefonu vsak dan najmanj od 8.00 do 16.00$)^{1} \vee$ obliki pisnih informacij (brošure, zloženke ipd.), ki so strankam dostopne $v$ vložišču, sprejemnem prostoru in na drugih ustreznih mestih ter na svetovnem spletu.

Informacije morajo biti podane na stranki razumljiv način. Strukturirane morajo biti po življenjskih položajih in morajo zajeti zlasti podatke o tem, kakšni so pogoji za pridobitev pravice oziroma upravne storitve, kje in po kakšnem postopku lahko stranka pridobi pravico oziroma upravno storitev, kaj je treba priložiti vlogi, kolikšna je višina upravne takse in morebitnih drugih plačil ter kako se lahko plačilo izvede.

Kot rečeno: opisani standard je nastal kot dedukcija dobre prakse. Hkrati pa se uporablja tudi kot izvedbeni standard k eni izmed zahtev, ki jih postavlja javni upravi letos sprejeti Zakon o dostopu do informacij javnega značaja (Uradni list RS, št. 24/2003), ki $v$ 10. členu med informacijami, ki jih mora vsak organ posredovati v svetovni splet, našteva tudi »podatke o upravnih storitvah«.

\subsection{Prostorska in časovna dostopnost}

Prostorska dostopnost se zagotavlja zlasti z ustrezno teritorialno razporejenostjo (dekoncentracijo) upravnih nalog. Sistem javne uprave $\vee$ Sloveniji v nasprotju s številnimi evropskimi sistemi temelji na ločitvi lokalne samouprave (občine) ${ }^{\mathbf{2}}$ in državne uprave - občinske uprave ne izvajajo državnih upravnih nalog. Vendar je

\footnotetext{
$1 \mathrm{~V}$ nekaterih organih so uvedli t. i. informatorja oziroma svetovalca za pomoč strankam. Za svetovalce za pomoč strankam $v$ upravnih enotah je bil pripravljen poseben program usposabljanja, ki jih seznani z vsemi področji dela upravne enote, vsemi postopki, upravnim okoljem upravne enote, veščinami komuniciranja s strankami itd. Svetovalec za pomoč strankam nudi strankam informacije o vseh storitvah upravne enote in po potrebi stranko naroči na točno določen dan in uro pri referentu, ki bo obravnaval njeno zahtevo.

2 Druge ravni lokalne samouprave Slovenija še nima, čeprav politične razprave o tem tečejo že vrsto let.
} 


\section{Gregor Virant \\ Usmerjenost k uporabniku kot načelo delovanja javne uprave}

mreža državne uprave razpršena tako, da je celotna država dobro teritorialno pokrita z upravnimi institucijami. Teritorialna organizacija državne uprave ni enotna, temveč so različna področja organizirana različno, pač glede na posebnosti področja, frekvenco upravnih postopkov in potrebe strank. Največ storitev za državljane (storitve na področju osebnih dokumentov, registracije prebivališča, matičnih zadev, graditve objektov, prometa s kmetijskimi zemljišči itd.) opravijo upravne enote, ki jih je 58 (povprečna upravna enota zajema približno 35.000 prebivalcev), večina drugih področij (davčna služba, carinska služba, policija, inšpekcije, geodetska služba, služba pokojninskega zavarovanja, služba za izvajanje politike zaposlovanja, služba obveznega zdravstvenega zavarovanja) pa je organizirana dvonivojsko (na prvi ravni imamo 8-12 območnih enot, na drugi ravni pa 20 - 58 izpostav).

Na posameznih področjih se pojavljajo težnje menedžmenta po organizacijski koncentraciji (ukinjanje izpostav), vendar je vlada sprejela odločitev, da se upravne storitve ne smejo oddaljevati od strank, razen $v$ primeru očitnih neracionalnosti. Pripravljen je tudi projekt reorganizacije upravnih enot, na podlagi katerega bi sistem 58 upravnih enot spremenili v sistem $8-12$ upravnih enot z 58 izpostavami; na ta način bi dosegli racionalizacijo na področju menedžmenta in podpornih (režijskih) služb, ne da bi s tem zmanjšali dostopnost storitev za uporabnike. Za izvajanje storitev se postopoma oblikuje mreža informatiziranih krajevnih uradov, ki praviloma delujejo dva- do trikrat na teden v prostorih občin (trenutno jih je nekaj čez 90). Novi pravilnik o krajevnih uradih določa, da krajevni uradi izvajajo osnovne, najpogostejše storitve (naštete so $\vee$ prilogi tega pravilnika), sprejemajo vloge, dajejo strankam informacije o vseh upravnih storitvah in jih po potrebi v zadevah, ki jih ne morejo opraviti sami, naročajo pri referentih na sedežu upravne enote. Oblikovanje krajevnega urada je organizacijska odločitev načelnika upravne enote, zagotovljeni pa morajo biti prostori, oprema in kadrovske rešitve. Uporabo prostorov in opreme lahko po dogovoru zagotovi tudi občina. Krajevni urad je lep primer partnerstva med državno upravo in lokalnimi skupnostmi.

Idealne rešitve za prostorsko dostopnost prinaša razvoj e-uprave. Transakcijska raven elektronskega poslovanja med javno upravo in uporabnikom omogoča pridobitev storitve iz domače dnevne sobe ali pisarne. Slovenska e-uprava žal ponuja malo storitev na tej ravni. Imamo pa zagotovljeno infrastrukturo, s katero bi lahko $\checkmark$ kratkem omogočili elektronsko naročanje vseh upravnih storitev. Od leta 2000 je elektronski podpis pravno izenačen z lastnoročnim podpisom, digitalna potrdila se $v$ velikem številu uporabljajo $v$ bančnem poslovanju (več kot 150.000 izdanih potrdil, medtem ko je število izdanih digitalnih potrdil državnega overitelja, SIGEN-CA, tako rekoč zanemarljivo). Nekateri komercialni ponudniki razvijajo aplikacije, ki uporabniku ponujajo obrazce vlog za upravne storitve, možnost plačila upravne takse in elektronskega podpisovanja vloge. Pripravljena je sprememba zakona o splošnem upravnem postopku, ki bo sprejeta spomladi naslednje leto in bo omogočila vzpostavitev enotnega informacijskega sistema (na državni ravni ga bo vzpostavil vladni 
center za informatiko) za sprejemanje vlog, vročanje in obveščanje o stanju zadeve. $\mathrm{Na}$ ta način bi lahko praktično z eno potezo odpravili zamudo, ki smo si jo nakopali z nekaterimi slabimi rešitvami ${ }^{3} \vee$ preteklosti.

\subsection{Enostavnost naročila, postopka in plačila}

Na področju poenostavljanja postopkov je bilo $\vee$ zadnjih letih storjenih nekaj pomembnih korakov. Na nekaterih upravnih področjih je prišlo do liberalizacije oziroma deregulacije. Ukinjena je bila odločba o izpolnjevanju pogojev za opravljanje gospodarske dejavnosti (4. člen zakona o gospodarskih družbah), ki jo je prej morala pred začetkom opravljanja katerekoli dejavnosti pridobiti vsaka gospodarska družba. Sprememba je sprostila preko 100 uslužbencev upravnih enot, ki so bili prerazporejeni na druge naloge na področjih, kjer so zaostanki največji (denacionalizacija, gradbene zadeve). Do liberalizacije je prišlo tudi na področju graditve objektov; novi zakon o graditvi objektov določa, da za enostavnejše objekte po novem ni potrebno niti gradbeno dovoljenje niti kakšna druga odločba.

Na nekaterih področjih pa je prišlo do poenostavljanja postopkov brez liberalizacije, torej brez posega $v$ javni interes. $V$ letu 2002 je bil spremenjen zakon o upravnih taksah, ki prinaša nove možnosti plačevanja upravnih taks. Takse je mogoče plačevati z gotovino, s kreditnimi in plačilnimi karticami in z drugimi "sodobnimi plačilnimi sredstvi« ( $v$ času pisanja tega prispevka potekajo pogajanja z operaterji mobilne telefonije o pogojih plačevanja taks po mobilnem telefonu). Upravne enote so že februarja 2003 (zakonski rok se je iztekel maja) zagotovile tehnične možnosti za plačevanje taks s t. i. plastičnim denarjem.

Pomembna je tudi sprememba zakona o upravnem postopku, ki uvaja načelo izmenjave podatkov iz uradnih evidenc med državnimi organi in organi lokalnih skupnosti. Zakonske določbe prepovedujejo organom javne uprave, da bi od uporabnikov zahtevali dokazila o podatkih, ki so $v$ uradnih evidencah. Takšne podatke morajo organi pridobiti sami. Omenjena zakonska določba je vplivala na pospešitev informatizacije in odpiranja podatkovnih baz (primeri: priključitev zavoda za pokojninsko in invalidsko zavarovanje na centralni register prebivalstva, priključitev upravnih enot in nekaterih drugih uporabnikov na bazo zemljiškega katastra) in na spremembe $\vee$ poslovnih procesih javne uprave $\vee$ smeri horizontalnega povezovanja. Sprememba je pomemben korak na poti k idealu "vse na enem mestu«.

3 Zlasti izključevanje digitalnih potrdil licenciranih overiteljev izven državne uprave pri poslovanju z upravo, izbira storitev, ki so bile informatizirane kot prve (izpiski iz matičnih knjig), zanemarjanje zasebne pobude in zanemarjanje področja, kjer so elektronske storitve najzanimivejše - tj. poslovanja med javno upravo in podjetji. 


\section{Gregor Virant \\ Usmerjenost k uporabniku kot načelo delovanja javne uprave}

\subsection{Kakovost osebnega stika, zanesljivost}

Na področju kakovosti osebnega stika moramo omeniti nove standarde poslovanja s strankami, kot so obvezna identifikacija uradne osebe (s tablico ali priponko), polje diskretnosti, uvedba svetovalca za pomoč strankam $v$ upravnih enotah, razvoj novih programov usposabljanja za svetovalce za pomoč strankam in programov $\mathrm{s}$ področja obvladovanja odnosov z uporabniki. Nekaj časa je potekalo tudi tekmovanje za uradnika meseca, vendar se je izkazalo, da so takšne akcije neprimerne in krivične do tistih uslužbencev, ki se redkeje srečujejo s strankami.

\subsection{Odzivnost}

Na področju odzivnosti uredba o poslovanju organov javne uprave s strankami prinaša dve pomembni obveznosti. Prva se nanaša na obravnavanje pripomb, kritik, predlogov in pohval strank. Predstojnik organa mora zagotoviti, da se tovrstna sporočila strank glede poslovanja organa obravnavajo in da se stranki odgovori najkasneje $\vee 30$ dneh. če stranka z odgovorom ni zadovoljna, se lahko obrne na organ, ki je pristojen za nadzor nad organom.

Drugo sredstvo odzivnosti je ugotavljanje kakovosti storitev oziroma zadovoljstva strank. Za upravne enote se ti postopki izvajajo na podlagi posebne metodologije, ki jo je pripravilo ministrstvo za notranje zadeve.

\section{4. Šibke točke in nadaljnja strategija}

Slovenska javna uprava je naredila pomembne korake pri usmerjanju k uporabniku. Trenutno obstaja precejšen »implementacijski razkorak» - razkorak med normativnim in stvarnim. Lahko bi rekli, da vemo, kaj od javne uprave na tem področju želimo in zahtevamo, in da smo to tudi zapisali $v$ predpise, $v$ nadaljevanju pa bomo morali poskrbeti za to, da se bodo "implementacijske škarje zapirale. Uresničiti bo treba določbe zakona o dostopu do informacij javnega značaja, ki postavljajo standarde podobe javne uprave (in širšega javnega sektorja) na svetovnem spletu. Napačno bi bilo, če bi se uresničevanja teh standardov lotil vsak organ posebej; potreben je usklajen, dobro voden projekt. Za lažje izvajanje določb zakona o upravnem postopku, ki predpisujejo izmenjavo podatkov iz uradnih evidenc, bo treba organom javne uprave odpreti možnost dostopa do sodnih baz podatkov.

Poskrbeti bo treba za to, da se novi pristopi usmerjenosti k uporabniku z upravnih enot razširijo tudi na druge organe javne uprave. Upravne enote so sicer pomemben del, a le del mozaika javne uprave, in tudi njihovi napori razvodenijo, če se izvajajo v okolju, ki takšnih pristopov ne uporablja. Kaj npr. pomaga stranki, če upravna enota zanjo pridobi podatke iz zemljiške knjige, če mora isti problem nato reševati pri notarju, ki še vedno zahteva izpisek iz zemljiške knjige? Kaj pomaga 
kakovostna informacija o gradbenem dovoljenju na internetu (za katero je pristojna upravna enota), če ob njej ni informacije o izvajanju enostavnih posegov $v$ prostor, za katere so pristojne občine?

Velik manevrski prostor imamo na področju poenostavljanja postopkov. Napori za odpravljanje administrativnih ovir so jalovi, če zavest ne prodre $v$ vse upravne resorje in se ne preneha praksa zapletanja postopkov. Med novimi predpisi je namreč še vedno več takih, ki postopke dodatno zapletajo, kot tistih, ki jih poenostavljajo.

Na področju e-uprave se nam ponuja možnost za preboj poslovanja "G2C" (uprava - državljani) in "G2B ( (uprava - podjetja), torej med upravo in uporabniki. Pripravljene so spremembe zakona o upravnem postopku, ki predvidevajo vzpostavitev enotnega informacijskega sistema za sprejemanje vlog, obveščanje in vročanje. Takšna horizontalna rešitev bo za upravo razmeroma poceni, omogočila pa bo hiter in širok razmah elektronskih storitev, zlasti če bo omogočila uporabo drugih kvalificiranih digitalnih potrdil. Elektronske vloge bodo organe javne uprave spodbujale, da zunanje elektronsko poslovanje (front office) povežejo z notranjimi procesi (back office), saj jim bodo elektronske vloge ponujale podatke $v$ elektronski obliki in možnost samodejne obdelave.

Slovenska uprava na področju usmerjenosti k uporabniku ubira pravo pot. Strateški cilji so začrtani, normativne podlage zagotovljene. Nadaljnji razvoj bo odvisen od izvedbene sposobnosti, ta pa predvsem od zavzetosti in zmogljivosti "strateških centrov « reforme uprave, pa tudi od posluha vlade za finančne potrebe na tem področju.

Doc. dr. Grega Virant je pridobil doktorat znanosti na Pravni fakulteti v Ljubljani. Njegova strokovna, znanstvena in raziskovalna dejavnost je usmerjena predvsem v naslednja področja: državna uprava, upravno pravo, lokalna samouprava, javne službe, državni posegi v lastnino, odškodninska odgovornost države, volilni sistem, referendum. Objavil je več člankov v domačih in tujih strokovnih in znanstvenih revijah. Na Ministrstvu za notranje zadeve je državni sekretar za organizacijo in razvoj uprave od junija 2000.

\section{SUMMARY}

\section{Orientation Towards Users as Principle of Public Administration Operations}

The principle of orientation towards the user, which is one of the so-called "new public administration" principles, has a significant role in the reform of public administrations of European countries. Governments pay special attention to the enhancement of quality of administration services. Public administration accepts this in a positive way, providing that political 
Gregor Virant

Usmerjenost k uporabniku kot načelo delovanja javne uprave

promises and actions are realistic and do not represent an unreasonable burden for its workers.

The essence of the principle of orientation towards the user is in the objective of reaching the highest possible level of satisfaction of the user with public administration services. In pursuing this objective, boundaries set by the public interest have to be respected. There are some hurdles on the way to a higher level of satisfaction by users of public administration services. Public administration does not function under market conditions and, therefore, is not forced to engage in a competition race for greater quality. Nonmarket mechanisms have to be used in order to improve the quality of its services. The top-down approach and the bottom-up approach should be combined. Administrative institutions, their managers and civil servant have direct contact and experience with users. Civil servants and their managers do not ignore the opinions their clients might have about them or their environment.

This is the reason why good practices emerge within the administration and wise governments promote them at the right moment to a wider circle of institutions or make them compulsory standards at the point when a critical mass has been reached. The strategic centre for public administration reform must be open for good ideas emerging from practice and must have a good sense for the right moment when good practices may be turned into compulsory standards. It is also a duty of the strategic centre to introduce new ideas and projects that the established domestic practice is at that time unfamiliar with (particularly those ideas which have already been established in other countries). Its important role is also in appropriately organising initiatives and information flow (by setting up project groups, quality boards, conferences on good practices, good practice competitions, etc.).

In order to achieve user satisfaction, the following elements of administration service are important: information about the service, accessibility in terms of location and time, simplicity of order, procedure and payment, quality of personal contact, expert level and professional appearance of workers, good organisation and conditions of the premises, appropriate response to criticism, comments, suggestions and praise as well as reliability. User satisfaction is essentially affected by the notion of respect for the "classical" values of public administration operation, namely the principles of legality, legal security and expectation, political neutrality and accountability of the public administration.

Information about administration services must be provided in various forms (by personal contact, telephone, e-mail, brochures and the Internet) so 
that users are guaranteed the freedom of choice. Information has to be provided in a user-friendly and intelligible format. It must answer key questions (where, how, when and how much?). The information system must be as uniform as possible. Ideally, a single information structure should be provided for all public administration services (e.g. a service portal on the Internet).

Accessibility in terms of location means that the user can order services and has all contacts necessary for the implementation of the service, in a location that is close to his/her home or business headquarters. Territorial organisation of the public administration is thus important as well as the introduction of new communication channels, in particular the development of e-administration. The development of e-administration enables contact with administration from home or office, if the public administration provides its services at transactions levels on the Internet. Electronic operations taking place between the administration and users bring about some added value mainly to businesses, since they have significantly more frequent contacts with the administration than the citizens.

Accessibility in terms of time means enabling the user to obtain a service in the shortest possible period of time. This provides for the shortening of queues and elimination of backlogs (dealing with cases in prescribed times).

Making administration procedures simple is very important for the enhancement of the quality of administration services. Simplified procedures save time and money. There should be a distinction between liberalisation and simplification of procedures in terms of their organisation and process. In the first case, the state is withdrawing from certain areas, abolishing obligatory licenses or reducing obligations for obtaining them (these are political decisions). The second type of procedure simplification has no political implications. Its essence is in the goal that the same public interest be protected to the same extent, but by making it simpler.

The quality of personal contact means an appropriate personal attitude of civil servants towards clients and managing relations with users. A kind attitude and a smile work miracles. Users of administration services attribute great importance to the quality of personal contact. It is important to place in the "front line" individuals with appropriate personal characteristics and capabilities and, at the same time, provide them with relevant training programmes.

Public administration institutions must respond to the opinions, assessments and wishes of their users. They must enable their users to report their criticisms, comments and suggestions as well as praise about their work. 


\section{Gregor Virant}

Usmerjenost $k$ uporabniku kot načelo delovanja javne uprave

They must respond to such messages in a reasonable time. Research on user satisfaction is also very important.

Since 1999 there have been systematic efforts carried out within the Slovene public administration to raise quality and user satisfaction. A number of projects and actions has been introduced, among which, for instance, there are the following: establishment of an e-administration service portal, definition of standards in operations with clients (with regard to information, response and personal contact), simplification of certain procedures (payment of administrative fees, abolition of certain licenses) and introduction of the principle that the administration must not demand clients to present proof of data already filed in official records.

The problem, which has yet to be overcome, is a gap between norms and actuality, between regulations and reality. The essence of the continuation of public administration reform is a consistent application of adopted laws and of implementing regulations in all areas. This shall be made possible by means of effective supervision, training of managers and other civil servants in the public administration as well as by changing the organisational culture of the public administration. 